\title{
Communication
}

\section{Anomalies of the Austrian Forest Fire Regime in Comparison with Other Alpine Countries: A Research Note}

\author{
Mortimer M. Müller ${ }^{1, *}$, Harald Vacik ${ }^{1}$ and Eva Valese ${ }^{2}$
}

1 Department of Forest- and Soil Sciences, University of Natural Resources and Life Sciences (BOKU), Institute of Silviculture, Peter Jordan Str. 82, 1190 Vienna, Austria;

E-Mail: harald.vacik@boku.ac.at

2 Veneto Region Civil Protection Bureau, Via Paolucci 34, 30175 Venice, Italy;

E-Mail: eva.valese@regione.veneto.it

* Author to whom correspondence should be addressed; E-Mail: mortimer.mueller@boku.ac.at; Tel.: +43-1-47654-4058; Fax: +43-1-47654-4092.

Academic Editor: Jianbang Gan

Received: 10 November 2014 / Accepted: 13 March 2015 / Published: 24 March 2015

\begin{abstract}
In recent years, Austria has experienced highly variable forest fire activity with new record values regarding the number of fires and sizes of burned areas. Single seasons in 2011, 2012 and 2013 showed 20-year-peaks and significant differences regarding fire activity. A statistical overview of datasets from Austria, Switzerland, Italy and Slovenia is given, allowing a preliminary comparison between the Alpine countries. Higher temperatures in combination with local dry weather conditions are hypothesized as reasons for the observed anomalies. Further analysis will be done with new climatic data in high spatial resolution from the "AgroDroughtAustria" project to confirm these preliminary findings.
\end{abstract}

Keywords: forest fire regime; Austria; Alps; alpine region; anomalies; climate change

\section{Introduction}

Austria is an Alpine Central European country with a forest cover of $47 \%$ mainly dominated by coniferous tree species. Forest fires in Austria play no major role compared to the damages and costs by other natural disturbances (e.g., storm, bark beetles). However, they are likely to become more important as expected impacts of climate change, socioeconomic changes and general trends in the provision of 
ecosystem services are supposed to evolve [1-7]. The exact consequences of these changes are unclear, due to a lack of knowledge in most of the influencing factors. The best investigated parameters that are coupled with the occurrence of forest fires are the meteorological conditions. Regional climate models suggest an increase in temperature and a reduction of precipitation in summer and autumn, especially in the south and east of Austria, which would likely lead to more frequent forest fires [8-11]. Since the 1980th, longtime trend of yearly mean temperature showed a steady increase, with 2014 being the warmest year ever recorded [12]. Annual precipitation had a high variance in the last decades but mostly increased since 10-20 years and stayed above long term average in recent years.

In 2008 the Institute of Silviculture at the University of Natural Resources and Life Sciences in Vienna started research on forest fires in Austria. Within the projects AFFRI (Austrian Forest Fire Research Initiative), ALP FFIRS (Alpine Forest Fire Warning System) and FIRIA (Fire Risk and Vulnerability of Austrian Forests under the Impact of Climate Change) more than 2700 forest fires were recorded from the period 1993 to 2014. Analysis on the occurrence, distribution, causes and characteristics of forest fires were accomplished [13]. Case studies, fuel investigations and fire behavior modeling followed basic research [14-16]. In 2013 a forest fire database and public accessible Web-GIS were developed to standardize the acquisition of forest fire data and to improve the access to recent findings [17].

In this short communication we want to present preliminary findings regarding the exceptional occurrence of forest fires in Austria and neighboring countries in recent years. What we primarily mean with the term "anomaly" is a deviation from the common rule without considering the amount of deviation of a (meteorological) quantity from the accepted normal value. We want to report an observation from the real world of fires to provide some words of caution.

\section{Alpine Fire History}

Valese et al. [7] showed that there were different fire epochs in the Alps, depending on human influence. Until the Neolithic period, fires were only ignited by lightning, leading to fire return intervals of 300 to 1000 years [18]. Progressively, as human population grew, fire became a tool for adapting the environment [19-21]. Approximately 150 years ago fire suppression policies came up for reasons associated with the protection of timber production [22]. The fire control approach led to a low number of wildfires first, but was followed by a shift to larger and intensified fires in the last decades [7,23].

In the south of Switzerland Tinner et al. [24] took pollen and charcoal data from the sediments of two lakes. They pointed out that fire played a major role in the past, at least in the south of the Alps. According to their findings, the occurrence of Abies alba, Mill., a species also very common in Austria, decreased according to higher fire frequency about 5000 years ago. Also other studies demonstrated that fires influenced vegetation dynamics in the Alps and changed tree composition [25-27]. Kral [28] investigated sediment and pollen samples from different lakes in Austria. He underlined the high variance of the occurrence of trees and perennials during the last centuries, driven $60 \%$ per human influence and $40 \%$ per climate. Still, no evidence was given on the potential impact of forest fires.

Many chronicles of municipalities and local field names in Austria hint at devastating forest fires before 1900 [29-32]. Reports of fires with a size up to 3000 hectares are known-almost thirty times as large as the biggest area burned in the past 100 years. Indeed, these examples seem to be exceptions and 
do not, according to the small number of events, provide a possibility to compile a historical fire pattern. Nevertheless they indicate a long fire history in the Alps [33].

\section{The Austrian Fire Regime}

The definition of "fire regime" lacks a clear and established definition, but often includes factors like frequency, intensity, extent, season and type of fire [34,35]. In Austria, the yearly distribution of these attributes greatly depends on regional weather conditions. These conditions are highly variable within the Alpine region, locally and temporally and during the whole year [36,37]. Because homogenized long-term data are missing and the number of yearly forest fires ranges around 200 incidents, most of them below one hectare in size, it is difficult to define a classical fire regime. Anyway, in the last 20 years, the period with a systematic collecting of forest fire data, the highest numbers of forest fires were found in spring, especially in March and April. A second smaller peak correlated with the summer months July and August. The major part of these fires occurred in Lower Austria, Carinthia and Tyrol, the southern and eastern parts of Austria [13]. Although it is difficult to draw conclusions on single years, it was observed that exceptions are becoming the rules in the last fire seasons [38,39]. To explain this phenomenon, we take a closer look at the years 2011,2012 and 2013 - three years which tend to indicate some "fire anomalies".

\section{Austrian Forest Fire Anomalies}

Table 1 shows the yearly distribution of the number of forest fires and the reported burned area in hectare from 1993 to 2013. The yearly standard deviation of fire incidents was $\sigma=50$ (spring), 42 (summer) and 10 (autumn), which nearly represents the seasonal mean values of forest fire events. Regarding the burned area, standard deviation ranged from $\sigma=33.9$ hectares (spring) to 34.8 ha (summer) and 6.1 ha (autumn), wherewith all three values lie above the seasonal mean values of burned area.

What we found in the three years 2011-2013 was a shift of seasonal fire peaks. Each year brought one exceptional strong accumulation of fire events during one season. In 2011 autumn brought along a never seen before outbreak of forest fires, in 2012 the same happened in spring and in 2013 the summer months followed the trend of seasonal fire anomalies (Table 2).

The year 2011 started with an exceptional high number of forest fires in spring. In contrast, summer fires were far below mean values. Then autumn came and brought the driest November ever documented in Austria [40]. Regions above high inversion fog experienced one of the warmest Novembers too. Nearly 50 forest fires burned 27 hectares of forest land between September and November. This sounds not very impressive, but exceeded the average fivefold - and made it the strongest autumn fire season recorded in the Austrian fire database. To test the significance of this pattern, a one-way ANOVA including a Post-hoc-Test considering the Games-Howell-Index was performed $(p<0.05)$. It was shown, that 2011 had a highly significant difference $(p=0.001)$ to most other years. Only the autumn seasons of the years 2006 and 2008, both including 21 forest fires, were not significantly different $(p=0.16)$, as well as the autumn season of $2003(p=0.07)$. 
Table 1. Numbers of forest fire events per season and seasonal burned area in hectares in Austria from 1993 to 2013.

\begin{tabular}{|c|c|c|c|c|c|c|}
\hline Year & Spring_n & Spring_ha & Summer_n & Summer_ha & Autumn_n & Autumn_ha \\
\hline 1993 & 75 & 55.3 & 29 & 27.9 & 2 & $0.0 *$ \\
\hline 1994 & 15 & 15.6 & 80 & 111.5 & 10 & 1.6 \\
\hline 1995 & 24 & 14.5 & 15 & 72.0 & 8 & 5.4 \\
\hline 1996 & 13 & 6.6 & 8 & 0.6 & 1 & $0.0 *$ \\
\hline 1997 & 24 & 12.5 & 5 & 4.1 & 5 & 8.2 \\
\hline 1998 & 35 & 54.5 & 17 & 8.9 & 1 & 0.7 \\
\hline 1999 & 8 & 3.2 & 4 & 2.4 & 3 & 0.1 \\
\hline 2000 & 17 & 6.6 & 18 & 34.8 & 3 & $0.0 *$ \\
\hline 2001 & 16 & 16.6 & 24 & 4.2 & 8 & 0.3 \\
\hline 2002 & 49 & 63.4 & 32 & 17.8 & 10 & 0.2 \\
\hline 2003 & 82 & 123.6 & 133 & 58.2 & 19 & 4.0 \\
\hline 2004 & 34 & 9.1 & 18 & 5.7 & 9 & 1.0 \\
\hline 2005 & 32 & 9.5 & 42 & 4.0 & 9 & 0.1 \\
\hline 2006 & 14 & 0.6 & 83 & 73.2 & 21 & 10.3 \\
\hline 2007 & 138 & 29.5 & 70 & 20.5 & 11 & 0.7 \\
\hline 2008 & 66 & 10.2 & 36 & 0.1 & 21 & 0.1 \\
\hline 2009 & 95 & 70.3 & 23 & 0.5 & 14 & 0.2 \\
\hline 2010 & 75 & 44.5 & 52 & 4.8 & 8 & $0.0 *$ \\
\hline 2011 & 150 & 31.2 & 45 & 25.6 & 45 & 27.4 \\
\hline 2012 & 184 & 56.5 & 48 & 1.1 & 8 & 1.5 \\
\hline 2013 & 10 & 2.6 & 172 & 107.0 & 10 & $0.0 *$ \\
\hline
\end{tabular}

Table 2. Number of fire events (first value) and total burned area in hectares (second value) for selected seasons in Austria compared to neighboring Alpine countries. "MeanAut", "MeanSpr" and "MeanSum" show the mean values for the analyzed seasons (autumn, spring and summer) in the last 20 years.

\begin{tabular}{ccccccc}
\hline Country & Autumn 2011 & MeanAut & Spring 2012 & MeanSpr & Summer 2013 & MeanSum \\
\hline Austria & $47 * \mid 27 *$ & $11 \mid 3$ & $184 * \mid 50$ & $57 \mid 23$ & $166 * \mid 107$ & $39 \mid 22$ \\
Switzerland (North) & $3 \mid 12 *$ & $3 \mid 1$ & $6 \mid 2$ & $7 \mid 19$ & $16 * \mid 1$ & $9 \mid 18$ \\
Switzerland (South) $^{*}$ & $2 \mid 0$ & $4 \mid 5$ & $8 \mid 11$ & $19 \mid 187$ & $4 \mid 20 *$ & $12 \mid 14$ \\
Italy (North-East $^{1}$ ) & $31 \mid 25$ & $19 \mid 52$ & $161 \mid 708$ & $93 \mid 506$ & $98 \mid 1482 * *$ & $80 \mid 238$ \\
Italy (North-West $^{2}$ ) & $57 \mid 221$ & $49 \mid 260$ & $200 \mid 1096$ & $275 \mid 2685$ & $18 \mid 10$ & $47 \mid 227$ \\
Slovenia $^{3}$ & $13 * \mid 71 *$ & $5 \mid 8$ & $68 \mid 92$ & $34 \mid 105$ & $40 \mid 47$ & $32 \mid 192$ \\
\hline
\end{tabular}

1 = Trentino (only 1999-2013), Veneto, Friuli; 2 = Piemonte, Lombardia (2013 missing), Aosta; 3 = Data from the Slovenia Forest Service/forest fire database; $*=$ Highest value since 1993; $* *=$ Highest 20 -year-value for Friuli.

The year 2012 was characterized by the highest number of spring fires ever recorded; and it came up with another surprise: The earliest ever documented lightning induced forest fire, ignited on 24 March. Normally $95 \%$ of lightnings - and 98\% of lightning induced forest fires - occur in the summer months from May to August [16,41]. The reasons for this lightning fire seemed to be the exceptional dry 
conditions combined with high temperatures and strong spring convection, which led to widespread thunderstorm evolution. The extraordinary high number of forest fires was likely caused by a severe drought since several months and the third warmest March ever recorded [42,43]. ANOVA analysis showed, that this season was significantly different to all other years, except for the spring season in 2011 $(p=0.26)$, where besides the drought in autumn another dry spring season occurred and forest fire activity was extraordinary high too.

The year 2013 started with the lowest number of spring fires since 1999 and the lowest burned area ever recorded, caused likely by a wet winter-one of the wettest ever recorded in Southern and Eastern Austria - as well as spring season and sunshine hours far below average [44]. After a flood disaster with heavy rainfall in many parts of Central Europe at the beginning of June, the forest fire year 2013 seemed to have taken an early end. However, from mid-July to mid-August, extremely hot and dry conditions were observed. July 2013 was the sunniest, driest and second warmest in more than 200 years of meteorological investigation in Austria. On the 8 August, temperatures in Austria exceeded 40 degrees Celsius for the first time since the beginning of scientific documentation in the year 1775 [45]. This situation led to an outbreak of 130 forest fires in Austria and a burned area of more than 100 hectares. Both numbers indicate the highest recorded values in the Austrian forest fire database, at least for this time of the year and the homogenized dataset since 1993. The largest fire in summer 2013 burned 53 hectares, which represents the largest area since 2002. ANOVA analysis with the number of seasonal fire events showed that summer 2013 had a highly significant difference $(p=0.001)$ to all other years except for summer 2003 ( $p=0.10)$, where a remarkable dry and hot August led to a comparable situation as in summer 2013.

Winter season 2013/2014 continued seasonal anomaly: it was the second warmest winter in Austria since more than 200 years [46]. In the south of the Alps precipitation was far above average, with amounts from $200 \%$ to $300 \%$ of an ordinary season. On the contrary, the north of Austria experienced very dry conditions with precipitation amounts under $40 \%$ of average. This corresponds to the lowest value since 150 years. Likely because of missing winter storms, rare foehn events and the altitude of the dry regions - mostly under $1000 \mathrm{~m}$ above sea level and so within the area of fog formation, which leads to wet and therefore unburnable fuel conditions- there were only some small forest fire events recorded.

\section{Comparison with Other Alpine Countries}

Several authors have identified large and extraordinary forest fires events in the Alpine region in recent years, often associated with heat waves and dry foehn winds, which is generally seen as an indication of a changing climate that may lead to new fire regimes in the Alps [23,47-50]. When comparing the described anomalies of the Austrian forest fire records with datasets from neighboring countries, there could be found some similarities, at least for the eastern parts of the Alpine region (Table 2). In autumn 2011, Slovenia also experienced a new record in number and burned area of forest fires. The north of Switzerland recorded the largest total burned area, but only three forest fires, which corresponds to average. In Italy the north-east saw more fires than in a typical season, yet the burned area was only half of the normal value. For spring 2012, also the north of Italy reported a never seen before lightning fire so early in the year that burned 300 hectares [7] very close to the southern border of Austria. Despite the high number of fires in Austria, there could not be found new record values in other countries. However, extraordinary 
high numbers of forest fires were documented in the north-east of Italy and in Slovenia. In north-west Italy and Switzerland, the number and sizes of burned areas stayed below average. In summer 2013, a new record in the number of forest fires was detected in the North of Switzerland. At the same time the fires in the South burned the largest area ever recorded in a summer season. The north-east of Italy experienced above-average numbers of fires and also burned areas, especially in the region bordering Austrian Carinthia (Friuli), while the north-west showed a below-average fire season. Slovenia observed slightly more fires than usual but only a quarter of the mean burned area (Table 2).

\section{Discussion}

Maybe the observed forest fire "anomalies" reflects the "normality", due to the variance of meteorological conditions in Austria [36,37]. Considering regional climate scenarios which predict more heatwaves and longer drought periods in summer and autumn, fire seasons like in 2011 and 2013 should become more frequent. Still, this future impact on the Alpine region is not that clear. While past regional climate model runs indicated a strong increase in temperature in the future — up to eight degree until 2100 [51,52] —actual findings in the context of IPCC5 pointed to the fact, that global and regional models have difficulties to reproduce the nearly stagnation in temperature increase during the last fifteen years and may overestimate the intensity and duration of heat waves [53,54].

The lightning fire in March 2012 may have been a strange coincidence. Dry periods in spring were frequent in the past, but combined with strong convection not associated with frontal systems - so called heat thunderstorms - they seem to be very rare in March [7]. There is an indication that the number of lightnings will increase with changing climatic conditions, which might influence the ignition patterns of forest fires as well [55].

When comparing the numbers of small forest fires below one hectare in size, there is a discrepancy to older fire data. Because forest fires have become better documented by fire brigades since the evolution of the World Wide Web, more small fires were found and collected. If we only take into account those fires which reached at least one hectare in size, the addressed anomalies and general significance levels from the years 2011, 2012 and 2013 remain unchanged. As a recent study showed, the Austrian fire database since 1993 is consistent regarding fires greater or equal one hectare in size [56]. It has also to be noted, that around half of the reported forest fires in the last 20 years lack information about the burned area. Yet we believe that most of these fires were small in size, as larger fires are generally better documented and can be found in different data sources. However, a sound statistical analysis would require a full data set for all records.

The small number of datasets used in this short communication is also a limitation of the current analysis. Because homogenized forest fire data in Austria is just available from 1993 onwards, we could utilize only 21 years for the analysis. For climate related comparative studies at least 30-year-data are used. However, the collection of forest fire data in Austria — and in other Alpine countries like Italy — is difficult, time-consuming and labor-intensive. A standardized and centralized collection of forest fire incidents does not exist. Additionally, forest structure and ownership are quite small scaled and dispersed. Around $56 \%$ of the forests in Austria are privately owned with an average size of less than 5 hectares per owner. However, continuous efforts will be made to enhance the data used for further analyzes, especially regarding the temporal extent. 
The differences/similarities between the selected forest fire data for Austria and the neighboring countries may be a result of Alpine weather patterns [52]. Because the eastern parts of the Alps show greater fire anomalies, precipitation during cyclone activity in the northern Mediterranean Sea might lead to wetter conditions in the western and dryer conditions in the eastern Alps. Spring seasons showed an increase in the number of drought periods during the last 20 years [57]. This correlates with more frequent spring fires - the four most active spring seasons occurred in the last seven years [13]. However, a period of 20 years is too short to conclude a tendency. In the late $80 \mathrm{~s}$ and early $90 \mathrm{~s}$ of the past century, the number and duration of dry intervals in spring was higher than in recent years. A short statistical overview for Vienna - located at the easternmost border of the Alps - showed that the duration and seasonal occurrence of drought periods in the last 250 years did not change significantly [57]. Indeed, this finding has to be proved with high resolution drought data, available from the "AgroDroughtAustria" project [58].

We hypothesize that it's not precipitation alone, which causes seasonal anomalies and influenced numbers and burned areas of forest fires, but a combination of drought periods and higher temperatures in the eastern Alpine region. To improve knowledge about the possible impact of climate behavior on forest fire occurrence it is planned to perform an analysis in 2015 with new data from the "AgroDroughtAustria" project, funded by the Austrian Climate Research Program, which has the goal to develop a drought monitoring system for Austria. We want therefore enhance the results of recent studies, which analyzed the link between weather and forest fire activity in the Alpine region [59,60].

Another possibility for the seasonal and regional increase of forest fire activity may be found in changed socioeconomic factors, like a shift in outdoor activities. Besides meteorological parameters, socioeconomic effects were found one of the main drivers in the occurrence of forest fires in Austria [5,61]. However, a combined interpretation of the relevant parameters is difficult to achieve on a larger scale as data on infrastructure, population density or other relevant anthropogenic parameters are not available on each scale.

\section{Acknowledgments}

We want to thank Marco Conedera (Switzerland) and Anže Japelj (Slovenia) for providing the requested datasets for the years 2011-2013 and Herbert Formayer (Institute of Meteorology) for the provision of meteorological data for Vienna. This research has been conducted partly within the frame of the Austrian Forest Fire Research Initiative (AFFRI), which is funded by the Austrian Science Fonds (FWF) within the Translational Research Program and the reference number L539-N14.

\section{Author Contributions}

Mortimer M. Müller compiled the dataset. Mortimer M. Müller and Harald Vacik analyzed the data. Eva Valese contributed with literature review and expert opinion. Mortimer M. Müller wrote the paper, with essential support from Harald Vacik and Eva Valese.

\section{Conflicts of Interest}

The authors declare no conflict of interest. 


\section{References}

1. Badeck, F.W.; Lasch, P.; Hauf, Y.; Rock, J.; Suckow, F.; Thonicke, K. Steigendes klimatisches Waldbrandrisiko. In Allgemeine Forstzeitschrift für Wald- und Forstwirtschaft (AFZ-DerWald); Deutscher Landwirtschaftsverlag GmbH: Hannover, Germany, 2003.

2. Barriopedro, D.; Fischer, E.M.; Luterbacher, J.; Trigo, R.M.; García-Herrera, R. The hot summer of 2010: Redrawing the temperature record map of Europe. Scienceexpress 2011, doi:10.1126/science.1201224.

3. Moreira, F.; Viedma, O.; Arianoutsou, M.; Curt, T.; Koutsias, N.; Rigolot, E.; Barbati, A.; Corona, P.; Vaz, P.; Xanthopoulus, G.; et al. Landscape-Wildfire interactions in southern Europe: Implications for landscape management. J. Environ. Manag. 2011, 92, 2389-2402.

4. Zumbrunnen, T.; Menéndez, P.; Bugmann, H.; Conedera, M.; Gimmi, U.; Bürgi, M. Human impacts on fire occurrence: A case study of hundred years of forest fires in a dry alpine valley in Switzerland. Reg. Environ. Chang. 2012, 12, 935-949.

5. Arndt, N.; Vacik, H.; Koch, V.; Arpaci, A.; Gossow, H. Modeling human-caused forest fire ignition for assessing forest fire danger in Austria. iForest 2013, doi:10.3832/ifor0936-006.

6. Seidl, R.; Schelhaas, M.J.; Rammer, W.; Verkerk, P.J. Increasing forest disturbances in Europe and their impact on carbon storage. Nat. Clim. Chang. 2014, doi:10.1038/nclimate2318.

7. Valese, E.; Conedera, M.; Held, A.C.; Ascoli, D. Fire, humans and landscape in the European Alpine region during the Holocene. Anthropocene 2014, 6, 63-74.

8. Matulla, C.; Formayer, H.; Haas, P.; Kromb-Kolb, H. Mögliche Klimatrends in Österreich in der ersten Hälfte des 21. Jahrhunderts. Österr. Wasser Abfallwirtsch. 2004, 56, 1-9.

9. Dankers, R.; Hiederer, R. Extreme Temperature and Precipitation in Europe: Analysis of a High-Resolution Climate Change Scenario; EUR 23291 EN; Office for Official Publications of the European Communities: Luxembourg, 2008.

10. Lautenschlager, M.; Keuler, K.; Wunram, C.; Keup-Thiel, E.; Schubert, M.; Will, A.; Rockel, B.; Boehm, U. Climate Simulation with CLM, Scenario A1B Run no.2, Data Stream 3: European Region MPI-M/MaD; World Data Center for Climate: Hamburg, Germany, 2009.

11. Fischer, E.M.; Schär, C. Consistent geographical patterns of changes in high-impact European heatwaves. Nat. Geosci. 2010, doi:10.1038/NGE0866.

12. Central Institute of Meteorology and Geodynamics Vienna. HISTALP Annual Report. Available online: http://www.zamg.ac.at/cms/de/dokumente/klima/dok_news/dok_histalp/jahresbericht-2014 (accessed on 28 January 2015).

13. Vacik, H.; Arndt, N.; Arpaci, A.; Koch, V.; Müller, M.M.; Gossow, H. Characterisation of forest fires in Austria. Aust. J. For. Sci. 2011, 128, 1-32.

14. Arpaci, A.; Valese, E.; Vacik, H. Potential fire intensities in the Alpine region based on characteristic fuels in Austria and Italy. In Proceedings of the 5th International Wildland Fire Conference, Sun City, South Africa, 9-13 May 2011.

15. Arpaci, A.; Eastaugh, C.S.; Vacik, H. Selecting the best performing fire weather indices for Austrian ecoregions. Theor. Appl. Climatol. 2013, 114, 393-406.

16. Müller, M.M.; Vacik, H.; Diendorfer, G.; Arpaci, A.; Formayer, H.; Gossow, H. Analysis of lightning-induced forest fires in Austria. Theor. Appl. Climatol. 2013, 111, 183-193. 
17. Vacik, H.; Müller, M.M. Waldbrand-Datenbank für Österreich. Wildbach Lawinenverbau 2013, 172, 188-189.

18. Pyne, S.J. Fire: A Brief History; Jeremy Mills Publishing: Huddersfield, UK, 2001.

19. Carcaillet, C.; Ali, A.A.; Blarquez, O.; Genries, A.; Mourier, B.; Bremond, L. Spatial variability of fire history in subalpine forests: From natural to cultural regimes. Ecoscience 2009, 16, 1-12.

20. Pausas, J.G.; Keeley, J.E. A burning story: The role of fire in the history of life. BioScience 2009, 59, 593-601.

21. Bond, W.J.; Woodward, F.I.; Midgley, G.F. The global distribution of ecosystems in a world without fire. New Phytol. 2005, 165, 525-538.

22. Conedera, M.; Vassere, S.; Neff, C.; Meurer, M.; Krebs, P. Using toponymy to reconstruct past land use: A case study of "brüsáda" (burn) in southern Switzerland. J. Hist. Geogr. 2007, 33, 729-748.

23. Pezzatti, G.B.; Zumbrunnen, T.; Bürgi, M.; Ambrosetti, P.; Conedera, M. Fire regime shifts as a consequence of fire policy and socio-economic development: An analysis based on the change point approach. For. Policy Econ. 2013, 29, 7-18.

24. Tinner, W.; Colombaroli, D.; Heiri, O.; Henne, P.D.; Steinacher, M.; Untenecker, J.; Vescovi, E.; Allen, J.R.M.; Carraro, G.; Conedera, M.; et al. The past ecology of Abies alba provides new perspectives on future responses of silver fir forests to global warming. Ecol. Monogr. 2013, 83, 419-439.

25. Blarquez, O.; Carcaillet, C.; Bremond, L.; Mourier, B.; Radakovitch, O. Trees in the subalpine belt since 11700 cal. BP: Origin, expansion and alteration of the modern forest. Holocene 2010, 20, 139-146.

26. Zumbrunnen, T.; Pezzatti, G.B.; Menéndez, P.; Bugmann, H.; Bürgi, M.; Conedera, M. Weather and human impacts on forest fires: 100 years of fire history in two climatic regions of Switzerland. For. Ecol. Manag. 2011, 261, 2188-2199.

27. Ascoli, D.; Bovio, G. Tree encroachment dynamics in heathlands of north-west Italy: The fire regime hypothesis. IForest 2010, 3, 137-143.

28. Kral, F. Spät- und postglaziale Waldgeschichte der Alpen aufgrund der bisherigen Pollenanalysen; Institute of Silviculture, University of Natural Resources and Life Sciences: Vienna, Austria, 1979; p. 175.

29. Die Geschichte der Marktgemeinde Brand-Nagelberg. Available online: http://www.brandnagelberg.at/main.php?menue=gemeinde\&geschichte (accessed on 28 January 2015).

30. Salzburg Wiki. Brände (Geschichte). Available online: http://www.salzburg.com/wiki/index. php/Br\%C3\%A4nde_\%28Geschichte\%29 (accessed on 28 January 2015).

31. Benediktinerabtei St. Georgenberg-Fiecht. Die Hohe Brücke über den Stallenbach. Available online: https://www.st-georgenberg.at/natur-2/hohe-bruecke.html (accessed on 28 January 2015).

32. Malowerschnig, B.; Sass, O. Long-term vegetation development on a wildfire slope in Innerzwain (Styria, Austria). J. For. Res. 2014, 25, 103-111.

33. Gobet, E.; Tinner, W.; Hochuli, P.A.; van Leeuwen, J.F.N.; Ammann, B. Middle to late holocene vegetation history of the Upper Engadine (Swiss Alps): The role of man and fire. Veg. Hist. Archaeobot. 2003, 12, 143-163. 
34. Krebs, P.; Pezzatti, G.B.; Mazzoleni, S.; Talbot, L.M.; Conedera, M. Fire regime: History and definition of a key concept in disturbance ecology. Theory Biosci. 2010, 129, 53-69.

35. Whelan, R.J. The Ecology of Fire; Cambridge University Press: Cambridge, UK, 1995.

36. Böhm, R.; Auer, I.; Brunetti, M.; Maugeri, M.; Nanni, T.; Schöner, W. Regional temperature variability in the European Alps: 1760-1998 from homogenized instrumental time series. Int. J. Climatol. 2001, 21, 1779-1801.

37. Hiebl, J.; Auer, I.; Böhm, R.; Schöner, W.; Maugeri, M.; Lentini, G.; Spinoni, J.; Brunetti, M.; Nanni, T.; Perčec Tadić, M.; et al. A high-resolution 1961-1990 monthly temperature climatology for the greater Alpine region. Meteorol. Z. 2009, 18, 507-530; doi:10.1127/0941-2948/2009/0403.

38. Gossow, H.; Hafellner, R. Es brennt - auch in Österreichs Wäldern. Fortschr. Landwirt 2006, 16, $14-15$.

39. Gossow, H.; Hafellner, R.; Vacik, H.; Huber, T. Major fire issues in the Euro-Alpine region-The Austrian Alps. Int. For. Fire News 2009, 38, 1-10.

40. Central Institute of Meteorology and Geodynamics Vienna. Wetterrückblick für November 2011. Available online: http://www.zamg.ac.at/cms/de/klima/klima-aktuell/monatsrueckblick/wetterrueckblick?monat $=11 \&$ jahr $=2011$ (accessed on 28 January 2015).

41. Schulz, W.; Cummins, K.L.; Diendorfer, G.; Dorninger, M. Cloud-to-ground Lightning in Austria: A 10-year study using data from a lightning location system. J. Geophys. Res. 2005, 110, doi:10.1029/2004JD005332.

42. Central Institute of Meteorology and Geodynamics Vienna. Wetterrückblick für März 2012. Available online: http:/www.zamg.ac.at/cms/de/klima/klima-aktuell/monatsrueckblick/wetterrueckblick?monat=03\&jahr=2012 (accessed on 28 January 2015).

43. Ali, A.A.; Blarquez, O.; Girardin, M.P.; Heĺy, C.; Tinquaut, F.; el Guellab, A.; Valsecchi, V.; Terrier, A.; Bremond, L.; Genries, A.; et al. Control of the multimillennial wildfire size in boreal North America by spring climatic conditions. Proc. Natl. Acad. Sci. USA 2012, 109, 20966-20970.

44. Central Institute of Meteorology and Geodynamics Vienna. Wetterrückblick für Februar 2013. Available online: http:/www.zamg.ac.at/cms/de/klima/klima-aktuell/monatsrueckblick/wetterrueckblick?monat=02\&jahr=2013 (accessed on 28 January 2015).

45. Central Institute of Meteorology and Geodynamics Vienna. Wetterrückblick für Juli 2013. Available online: http:/www.zamg.ac.at/cms/de/klima/klima-aktuell/monatsrueckblick/wetterrueckblick?monat=07\&jahr=2013 (accessed on 28 January 2015).

46. Central Institute of Meteorology and Geodynamics Vienna. Zweitwärmster Winter der Messgeschichte. Available online: http://www.zamg.ac.at/cms/de/klima/news/zweitwaermsterwinter-der-messgeschichte (accessed on 28 January 2015).

47. Wohlgemuth, T.; Hester, C.; Jost, A.R.; Wasem, U.; Moser, B. Recruitment dynamics following the forest fire near Leuk (Valais). J. For. Suisse 2010, 161, 450-459.

48. Schär, C.; Vidale, P.L.; Lüthi, D.; Frei, C.; Häberli, C.; Liniger, M.A.; Appenzeller, C. The role of increasing temperature variability in European summer heatwaves. Nature 2004, 427, 332-336. 
49. Conedera, M.; Cesti, G.; Pezzatti, G.B.; Zumbrunnen, T.; Spinedi, F. Lightning-induced fires in the Alpine region: An increasing problem. In V International Conference on Forest Fire Research 2006, Figueira da Foz, Portugal, Coimbra, Portugal, 27-30 November 2006; Viegas, D.X., Ed.; ADAI/CEIF University of Coimbra: Coimbra, Portugal, 2006.

50. Matulla, C.; Formayer, H.; Haas, P.; Kromp-Kolb, H. Possible climate trends in Austria in the first half of the 21 st century. Österr. Wasser Abfallwirtsch. 2004, 56, 1-9.

51. Fischer, A.M.; Weigel, A.P.; Buser, C.M.; Knutti, R.; Künsch, H.R.; Liniger, M.A.; Schär, C.; Appenzeller, C. Climate change projections for Switzerland based on a Bayesian multi-model approach. Int. J. Climatol. 2012, 32, 2348-2371.

52. Arpaci, A.; Cane, D.; Pezzatti, G.B.; Barbarino, S.; Valese, E.; Conedera, M.; Vacik, H. Suitability of Fire Weather Indices for Alpine conditions: An evaluation based on weather station data. Int. J. Climatol. 2015, submitted.

53. Cattiaux, J.; Douville, H.; Peings, Y. European temperatures in CMIP5: Origins of present-day biases and future uncertainties. Clim. Dyn. 2013, 41, 2889-2907.

54. Vautard, R.; Gobiet, A.; Jacob, D.; Belda, M.; Colette, A.; Déqué, M.; Fernández, J.; García-Díez, M.; Goergen, K.; Güttler, I.; et al. The simulation of European heat waves from an ensemble of regional climate models within the EURO-CORDEX project. Clim. Dyn. 2013, 41, 2555-2575.

55. Yair, Y.; Lynn, B.; Price, C.; Kotroni, V.; Lagouvardos, K.; Morin, E.; Mugnai, A.; Llasat, M.C. Predicting the potential for lightning activity in Mediterranean storms based on the Weather Research and Forecasting (WRF) model dynamic and microphysical fields. J. Geophys. Res. 2010, 115, doi:10.1029/2008JD010868.

56. Eastaugh, C.S.; Vacik, H. Fire size/frequency modelling as a means of assessing wildfire database reliability. Aust. J. For. Sci. 2012, 129, 228-247.

57. Formayer, H. Institute of Meteorology, University of Natural Resources and Life Sciences, Vienna, Austria. Personal Communication, 2014.

58. Scientific Information System (FIS), University of Natural Resources and Life Sciences Vienna. Available online: https://forschung.boku.ac.at/fis/suchen.projekt_uebersicht?sprache_in=en\&menue_id_in=300\&id_in=9555 (accessed on 30 January 2015).

59. Zumbrunnen, T.; Bugmann, H.; Conedera, M.; Bürgi, M. Linking forest fire regimes and climate-A historical analysis. Ecosystems 2009, 12, 73-86; doi:10.1007/s10021-008-9207-3.

60. Wastl, C.; Schunka, C.; Lüpke, M.; Cocca, G.; Conedera, M.; Valese, E.; Menzel, A. Large-scale weather types, forest fire danger, and wildfire occurrence in the Alps. Agric. For. Meteorol. 2013, $168,15-25$.

61. Arpaci, A.; Malowerschnig, B.; Sass, O.; Vacik, H. Using multi variate data mining techniques for estimating fire susceptibility of Tyrolean forests. Appl. Geogr. 2014, 53, 258-270.

(C) 2015 by the authors; licensee MDPI, Basel, Switzerland. This article is an open access article distributed under the terms and conditions of the Creative Commons Attribution license (http://creativecommons.org/licenses/by/4.0/). 